\title{
The potential of CD127 as a prognostic and residual disease marker in chronic adult T cell leukaemia/lymphoma
}

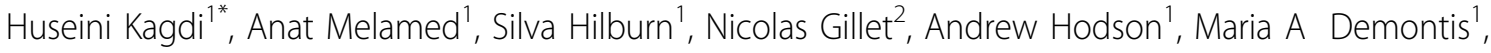 \\ Aileen Rowan', Lucy Cook', Charles Bangham', Graham Taylor ${ }^{1}$ \\ From 16th International Conference on Human Retroviruses: HTLV and Related Viruses \\ Montreal, Canada. 26-30 June 2013
}

Adult T cell Leukaemia Lymphoma [ATL], a mature T-cell neoplasm has been classified into 4 subtypes: smouldering; chronic leukaemia; lymphoma and acute leukaemia. The diagnosis depends on clinical features, the immunophenotype, and demonstration of HTLV-1 infection \& ideally of monoclonal proviral integration. The typical immunophenotype of ATL is not specific. The methods used to detect monoclonality are labour-intensive and/or expensive and are not widely available. We developed a flow cytometry assay for diagnosis and monitoring of ATL. We performed 11-colour immunophenotyping, HTLV-1 proviral quantification and proviral integration site [IS] analysis on 53 samples from 36 patients [25 non ATL HTLV-1-infected, 11 chronic/smouldering ATL], 3 uninfected individuals and 2 HTLV-1-immortalized cell lines. The non-ATL patients had CD127+ \& CCR7-lo expression in CD4+ CD25+CCR4+ cells, and a polyclonal distribution on IS analysis. FourATL patients had CD127+ \& CCR7-lo expression in CD4+CD25+CCR4+ cells and polyclonal distribution on IS analysis. These patients had an excellent outcome achieving remission with either PUVA or no therapy. Eight ATL patients had CD127-lo expression on CD4+ CD25+ CCR4+ cells with mono/oligoclonal distribution on IS analysis. One of nine patients with chronic ATLL had high CCR7 expression. Foxp3 expression was variable. All 8 patients required systemic ATL treatment and longitudinal study of 5 patients found the change in frequency of CD4+CD25+CCR4+ to correlate with PVL whilst CD127 expression correlated with IS analysis $(p<0.005)$ and disease remission status. CD127 expression

\footnotetext{
* Correspondence: hkagdi@imperial.ac.uk

'Infectious Diseases and Immunology, Faculty of Medicine, Imperial College, London, UK

Full list of author information is available at the end of the article
}

appears to be useful to identify patients needing treatment and for monitoring the treatment of chronic ATL.

\section{Authors' details}

${ }^{1}$ Infectious Diseases and Immunology, Faculty of Medicine, Imperial College, London, UK. ${ }^{2}$ Molecular and Cellularepigenetics, Interdisciplinary Cluster for Applied Genoproteomics (GIGA) of University of Liège, Leige, Belgium.

Published: 7 January 2014

doi:10.1186/1742-4690-11-S1-P140

Cite this article as: Kagdi et al:: The potential of CD127 as a prognostic and residual disease marker in chronic adult T cell leukaemia/ lymphoma. Retrovirology 2014 11(Suppl 1):P140.
Submit your next manuscript to BioMed Central and take full advantage of:

- Convenient online submission

- Thorough peer review

- No space constraints or color figure charges

- Immediate publication on acceptance

- Inclusion in PubMed, CAS, Scopus and Google Scholar

- Research which is freely available for redistribution

Submit your manuscript at www.biomedcentral.com/submit
() Biomed Central 